\title{
Unusual Ergot Alkaloid Biosynthesis in Sclerotia of a Claviceps purpurea Mutant
}

\author{
By JUlia Willingale, SUSAN M. ATWELl and P. G. MANTLE* \\ Biochemistry Department, Imperial College, London SW7 2AZ, U.K.
}

(Received 22 October 1982; revised 28 January 1983)

\begin{abstract}
A strain of Claviceps purpurea, which has consistently failed to elaborate ergot alkaloids when growing as a parasite, has been shown to perform only the first step of the ergoline biosynthetic pathway catalysed by dimethylallyltryptophan (DMAT) synthetase. The next step, involving $\mathrm{N}$ methylation of DMAT, did not operate. $\left[{ }^{14} \mathrm{C}\right]$ Agroclavine and lysergic acid, normally intermediates in alkaloid biosynthesis, were accepted by parasitic sclerotial tissue as substrates and were metabolized to lysergic acid amide (LAA). This amide therefore constituted a previously unreported end product for $C$. purpurea. It is concluded that the mutant has a metabolic block in the pathway following DMAT and, while enzymes for several subsequent steps are present, the fungus seems unable to form the usual cyclic tripeptide ergot alkaloids. The steps involved in metabolizing agroclavine to LAA were insensitive to $1 \mathrm{M}$-phosphate, while this concentration of phosphate completely inhibited DMAT synthetase. This double mutant therefore has unique potential for exploring control mechanisms in ergot alkaloid biosynthesis.
\end{abstract}

\section{INTRODUCTION}

Claviceps purpurea almost invariably elaborates ergot alkaloids during sclerotial development in the florets of host plants. The alkaloids vary considerably in amount, but form the principal toxic component of sclerotia. As a source of important pharmaceuticals much attention has been given to the biosynthetic pathway, reviewed recently by Floss \& Anderson (1980). The principal steps in the pathway to the cyclic tripeptide ergot alkaloids (e.g. ergotamine) are as follows: tryptophan + dimethylallyl pyrophosphate $\rightarrow$ dimethylallyltryptophan $\rightarrow N$-methyl dimethylallyltryptophan $\rightarrow$ chanoclavine $\rightarrow$ agroclavine $\rightarrow$ elymoclavine $\rightarrow$ lysergic acid $\rightarrow$ cyclic tripeptide ergot alkaloids. Some enzymes have been isolated and there has recently been progress in exploring the difficult area of biosynthetic control mechanisms in this group of secondary metabolites. There is evidence that phosphate may have a regulatory function (Krupinski et al., 1976). It is usual for $C$. purpurea to synthesize one or more cyclic tripeptide derivatives of lysergic acid (e.g. ergotamine, ergocornine, ergocryptine) as the end products of this aspect of its secondary metabolism. Short-chain lysergic acid derivatives (e.g. ergometrine) may also occur but the simplest derivative, lysergic acid amide (LAA), only occurs as a product of Claviceps paspali (Arcamone et al., 1961), possibly as an artefact from spontaneous decomposition of lysergic acid $\alpha$-hydroxyethylamide (Floss \& Anderson, 1980), and in seed of some Convolvulaceous plants (Hofmann \& Tscherter, 1960). Variants which fail to produce alkaloid but which are apparently typical $C$. purpurea are rare, but one such (Corbett et al., 1974) has been available for over 20 years and has consistently been alkaloid-free when parasitizing rye or wheat. This paper seeks to explain in biochemical terms the reason for this failure to produce alkaloids and recognizes the potential of this apparently stable mutant for research on metabolic control in parasitic tissue.

Abbreviations: DMAT, dimethylallyltryptophan; LAA, lysergic acid amide; PLC, preparative layer chromatography. 


\section{METHODS}

Organisms. Claviceps purpurea strain 12-2 was originally isolated in 1960 from a sclerotium collected from rye at Tarporley, Cheshire. Sclerotia produced by this isolate on rye failed to produce tetracyclic ergoline alkaloids during parasitic development (Corbett et al., 1974). The glucan-autolysing isolate of Claviceps fusiformis, designated 139/2/1G (Dickerson et al., 1970) was used for its ability to biosynthesize agroclavine.

Radioisotopes. DL-[2-14 C]Mevalonic acid lactone (sp.act. $18 \mathrm{mCi} \mathrm{mmol}^{-1}$ ) $[1 \mathrm{mCi}=37 \mathrm{MBq}]$, L- $[$ methyl${ }^{14} \mathrm{C}$ ]methionine (sp.act. $60 \cdot 2 \mathrm{mCi} \mathrm{mmol}^{-1}$ ), $\mathrm{L}$-[methylene $\left.{ }^{-14} \mathrm{C}\right]$ tryptophan (sp.act. $58 \cdot 2 \mathrm{mCi} \mathrm{mmol}^{-1}$ ) and reference standard $n-\left[{ }^{14} \mathrm{C}\right]$ hexadecane (sp.act. $0.863 \times 10^{6} \mathrm{~d}$.p.m. ml ${ }^{-1}$ ) were products of Amersham International.

Preparation of $\left[{ }^{14} \mathrm{C}\right]$ agroclavine. Erlenmeyer flasks $(500 \mathrm{ml})$ containing sucrose/asparagine medium $(100 \mathrm{ml})$ were inoculated with a $5 \%(\mathrm{v} / \mathrm{v})$ transfer from a $7-\mathrm{d}$ seed flask culture of $C$. fusiformis strain 139/2/1G (Banks et al., 1974). The mycelium was dispersed by agitation and then allowed to float to form a surface culture which was incubated stationary at $27^{\circ} \mathrm{C}$. After $6 \mathrm{~d}$ a mixture of DL- $\left[2-{ }^{14} \mathrm{C}\right]$ mevalonic acid $(25 \mu \mathrm{Ci}$, prepared by evaporating the benzene carrier and neutralizing with $1 \mathrm{M}-\mathrm{NaOH})$ and $\mathrm{L}-\left[\right.$ methyl $\left.{ }^{14} \mathrm{C}\right]$ methionine $(25 \mu \mathrm{Ci}$ in aqueous solution) was injected into the medium beneath the mycelial mat with a hypodermic syringe, and mixed by gentle rotation. Cultures were incubated for a further $9 \mathrm{~d}$ at $27^{\circ} \mathrm{C}$. Alkaloid production was monitored colorimetrically (Banks $e t$ $a l ., 1974)$ at 7 and $16 \mathrm{~d}$. Extracted clavine alkaloids were resolved by preparative layer chromatography (PLC) on silica gel GF254 (1 mm layer) in chloroform/methanol/ammonia ( $95: 7: 5$, by vol.). Subsequent autoradiography of the resolved plate revealed incorporation of ${ }^{14} \mathrm{C}$ into one principal product co-chromatographing with authentic agroclavine.

Radiolabelled agroclavine was purified by recrystallization from petroleum ether (b.p. $100-120^{\circ} \mathrm{C}$ ) to constant specific activity $\left(19.96 \mu \mathrm{Ci} \mathrm{mmol}{ }^{-1}\right)$. This purified product was stored in a covered desiccator at $4{ }^{\circ} \mathrm{C}$ before

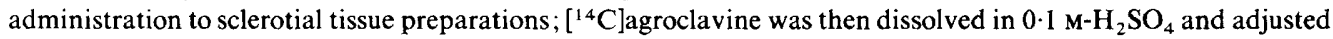
to $\mathrm{pH} 6$ with dilute $\mathrm{NaOH}$.

Growth and preparation of parasitic tissue. Parasitic sclerotial tissue was grown on Svalof's Fourex rye in open plots at Chelsea Physic Garden, London, as previously described (Corbett et al., 1974). Actively growing sclerotia were harvested from inoculated ears, washed and sectioned. The youngest (proximal) and oldest (distal) $3 \mathrm{~mm}$ of tissue was discarded. The remaining tissue from the middle of the sclerotia was briefly macerated in a Sorvall omnimixer and distributed evenly to a series of Erlenmeyer flasks $(250 \mathrm{ml})$ containing $2 \mathrm{mmol}$ glucose plus tetracycline $\left(50 \mu \mathrm{g} \mathrm{m}^{-1}\right)(40 \mathrm{ml})$. However, bacterial counts made before and after subsequent incubation at $24^{\circ} \mathrm{C}$ indicated that the antibiotic used was ineffective in suppressing bacterial growth over the incubation period. For assessment of biosynthetic activity in different regions of the sclerotium the above procedure was repeated, except that separated distal and proximal $3 \mathrm{~mm}$ regions were not discarded but were assayed for dimethylallyltryptophan (DMAT).

Incubation of fresh parasitic tissue with labelled precursors. After addition of radiolabelled precursor and, in some instances, of $\mathrm{KH}_{2} \mathrm{PO}_{4}$, flasks containing primary precursors or intermediates were incubated at $27^{\circ} \mathrm{C}$ on a rotary shaker (200 r.p.m., $10 \mathrm{~cm}$ eccentric throw) in the dark for $24 \mathrm{~h}$ or $48 \mathrm{~h}$, respectively. Sclerotial tissue was separated from the incubation fluid by centrifugation at $15000 \mathrm{~g}$ for $15 \mathrm{~min}$, and washed to remove unabsorbed label. Tissue and supernatants were stored as lyophilized residues at $4{ }^{\circ} \mathrm{C}$ in the dark prior to counting and/or extraction.

Tissue oxidation. Rapid determination of the amounts of label present in the tissues before and after alkaloid extraction was achieved by oxidizing lyophilized tissue $(150 \mathrm{mg}$ ) in a sample oxidizer (Intertechnique, model 4101). ${ }^{14} \mathrm{CO}_{2}$ released from the samples during oxidation was automatically absorbed into $15 \mathrm{ml}$ scintillant (toluene/phenylethylamine/methanol/water, $4: 3 \cdot 3: 2 \cdot 2: 0 \cdot 5$, by vol., and butyl-PBD, $7 \mathrm{~g} \mathrm{l}^{-1}$ ), which was subsequently counted. Overall efficiency of oxidation and scintillation was determined using tissue paper impregnated with $10 \mu \mathrm{l} n-\left[{ }^{14} \mathrm{C}\right]$ hexadecane.

Extraction of sclerotial tissue for basic and amphoteric metabolites. Lyophilized tissue (1-2 g) and $\mathrm{NaHCO}_{3}(0 \cdot 3 \mathrm{~g})$ were mixed with a little water and extracted exhaustively with diethyl ether $(2 \times 100 \mathrm{ml})$ for $2 \mathrm{~h}$. Ether extracts were combined and taken to dryness in vacuo. Tissues rendered free of bases by the above procedure were further extracted for $2 \mathrm{~h}$ with methanol $(2 \times 100 \mathrm{ml})$ to remove amphoteric alkaloids. The methanol was evaporated, and the residue was taken up in $0.025 \mathrm{M}-\mathrm{HCl}$ and applied to a column of Zeolite $\mathrm{C} 225\left(\mathrm{H}^{+}\right)$cation-exchange resin. Amphoteric alkaloids were dissociated from the resin with $5 \mathrm{M}-\mathrm{NH}_{4} \mathrm{OH}$ and lyophilized. All ether extracts and lyophilized residues were stored at $4{ }^{\circ} \mathrm{C}$ in the dark until analysed.

Separation of some ${ }^{14} \mathrm{C}$-labelled metabolites. Amphoteric components were separated by PLC and TLC (Polygram SIL G/UV ${ }_{254}$, Camlab) by developing chromatograms twice in chloroform/methanol/ammonia $(80: 20: 6$, by vol.), against markers of authentic tryptophan and DMAT. Resolved plates were autoradiographed using prefogged Fuji Safety $5 \mathrm{X}$-ray film for $4-7 \mathrm{~d}$ at $-70^{\circ} \mathrm{C}$ to locate radiolabel. Indole derivatives were located by shield spraying a part of each plate with Ehrlich's reagent. Unsprayed regions corresponding to DMAT were eluted with excess methanol and taken to dryness. The residues were subjected to preparative HPLC on a reversed-phase Altex Ultrasphere-ODS column $(250 \times 10 \mathrm{~mm})$ using methanol/water $(5: 1, \mathrm{v} / \mathrm{v})$ and UV detection at $235 \mathrm{~nm}$, and fractions were collected. The fraction having a retention time corresponding to authentic 
DMAT was taken to dryness of a planchet and counted in a Nuclear Chicago low-background counter (model $\mathrm{C} 155)$ operated at $2100 \mathrm{~V}\left(11.4 \%\right.$ efficiency using $n-\left[{ }^{14} \mathrm{C}\right]$ hexadecane $)$. Separation of basic ergot alkaloids was performed by PLC in ethyl acetate/dimethyl formamide/ethanol (13:1.9:0.1, by vol.) (McLaughlin et al., 1964) or by TLC in a less polar mixture $(26: 2: 0 \cdot 1)$ of the same solvents. Subsequent modified TLC, using chloroform/methanol $(4: 1, v / v)$, gave optimum resolution of the principal alkaloid at $R_{F} \sim 0 \cdot 5$. Autoradiography was as above, and the principal ${ }^{14} \mathrm{C}$-labelled alkaloid was eluted and counted as above.

Mass spectrometry. Alkaloids were taken up in methanol from the planchets used for radioactivity counting and analysed by electron impact mass spectrometry.

\section{RESULTS}

The first step of the ergot alkaloid biosynthetic pathway was explored by incubating fresh tissue of partially developed ergot sclerotia with radioactive precursors, tryptophan, methionine and mevalonic acid. The results, summarized in Table 1 , demonstrate conclusively that DMAT was biosynthesized during the incubation period. Radiolabel was not detected in any chromatographic region in which Claviceps purpurea alkaloids are normally found nor was there any evidence of ergot alkaloids having been present in the tissue prior to incubation. Consequently, further fresh ergot tissue which had not been incubated with labelled compounds was analysed using TLC and HPLC systems selecting for amphoteric indole derivatives; trace

Table 1. Biosynthetic products from incorporation of precursors or intermediates administered to parasitic tissue of a strain of Claviceps purpurea

\begin{tabular}{|c|c|c|c|c|c|c|}
\hline \multirow{2}{*}{$\begin{array}{l}\text { Dry wt of } \\
\text { ergot tissue } \\
\text { (g) }\end{array}$} & \multirow[b]{2}{*}{ Precursor added } & \multirow{2}{*}{$\begin{array}{c}\text { Sp.act. } \\
\text { of precursor } \\
\left(\mu \mathrm{Ci} \mathrm{mmol}^{-1}\right)\end{array}$} & \multirow{2}{*}{$\begin{array}{c}\text { Percentage } \\
\text { (and amount) of } \\
\text { metabolizable } \\
\text { radiolabel taken } \\
\text { up and retained } \\
\text { by ergot tissue }\end{array}$} & \multicolumn{2}{|c|}{$\begin{array}{c}{ }^{14} \mathrm{C} \text {-labelled metabolites } \\
\text { detected } \\
\text { by autoradiography }\end{array}$} & \multirow{2}{*}{$\begin{array}{l}\text { Calculated } \\
\text { yield of } \\
\text { LAA } \\
(\mu \mathrm{g})\end{array}$} \\
\hline & & & & DMAT & Ergot alkaloids & \\
\hline 1.53 & $\begin{array}{l}\text { L- }\left[22^{-14} \mathrm{C}\right] \text { Tryptophan } \\
(3 \mu \mathrm{Ci})\end{array}$ & $58.2 \times 10^{3}$ & $61 \%(1.83 \mu \mathrm{Ci})$ & + & - & - \\
\hline 1.07 & $\begin{array}{l}\text { DL- }\left[2-^{14} \mathrm{C}\right] \text { Mevalonate } \\
(10 \mu \mathrm{Ci}) \\
\text { L- }[\text { methyl-14 } \mathrm{C}] \text { Methionine }\end{array}$ & $18 \times 10^{3}$ & $7 \cdot 4 \%(0 \cdot 74 \mu \mathrm{Ci})$ & + & - & - \\
\hline $\begin{array}{l}1.99 \\
6 \cdot 08\end{array}$ & $\begin{array}{l}(5 \mu \mathrm{Ci}) \\
{\left[{ }^{14} \mathrm{C}\right] \text { Agroclavine }}\end{array}$ & $56.7 \times 10^{3}$ & $82 \cdot 3 \%(4 \cdot 12 \mu \mathrm{Ci})$ & - & - & - \\
\hline & $(0.57 \mu \mathrm{Ci})$ & 19.96 & $9 \cdot 1 \%(0.052 \mu \mathrm{Ci})$ & - & $\begin{array}{c}\stackrel{+}{(\text { LAA } 4.8 \%} \\
\text { Agroclavine } 95.2 \%)\end{array}$ & 45 \\
\hline 3.98 & $\begin{array}{l}\text { Lysergic acid, } 2 \mathrm{mg} \\
\text { (not radiolabelled) }\end{array}$ & - & - & - & $\begin{array}{c}+ \\
(\mathrm{LAA}>90 \% \\
\text { not radiolabelled })\end{array}$ & 188 \\
\hline
\end{tabular}

Table 2. Effect of phosphate concentration in the incubation mixture on C. purpurea metabolism of precursors to products in the ergot alkaloid biosynthetic pathway

\begin{tabular}{|c|c|c|c|c|c|}
\hline $\begin{array}{l}\text { Dry wt of } \\
\text { ergot tissue } \\
(\mathrm{g})\end{array}$ & $\begin{array}{l}\text { Concn of } \\
\text { phosphate } \\
\text { buffer } \\
\text { (M) }\end{array}$ & Precursor added* & $\begin{array}{l}\text { Percentage } \\
\text { (and amount) of } \\
\text { radiolabel taken } \\
\text { up and retained } \\
\text { by ergot tissue }\end{array}$ & $\begin{array}{l}\text { Principal anabolic } \\
\text { products in alkaloid } \\
\text { biosynthesis }\end{array}$ & $\begin{array}{c}\text { Conversion of } \\
\text { precursor to } \\
\text { to product } \\
(\%)\end{array}$ \\
\hline 1.85 & 0 & $L-\left[2-^{14} \mathrm{C}\right]$ Tryptophan & $28.59(1.29 \mu \mathrm{Ci})$ & {$\left[{ }^{14} \mathrm{C}\right] \mathrm{DMAT}$ (13566 d.p.m.) } & $0 \cdot 14$ \\
\hline $2 \cdot 32$ & $0 \cdot 01$ & $L-\left[2-{ }^{14} \mathrm{C}\right]$ Tryptophan & $21.26(0.96 \mu \mathrm{Ci})$ & {$\left[{ }^{14}\right.$ C]DMAT (42147 d.p.m.) } & $0 \cdot 43$ \\
\hline $2 \cdot 11$ & $0 \cdot 1$ & $L-\left[2-{ }^{14} \mathrm{C}\right]$ Tryptophan & $26.58(1.20 \mu \mathrm{Ci})$ & {$\left[{ }^{14}\right.$ C]DMAT (23465 d.p.m.) } & $0 \cdot 24$ \\
\hline $2 \cdot 36$ & $1 \cdot 0$ & $\mathrm{~L}-\left[2{ }^{14} \mathrm{C}\right]$ Tryptophan & $43.95(1.98 \mu \mathrm{Ci})$ & none $(-)$ & - \\
\hline $3 \cdot 50$ & 0 & Agroclavine & $\ldots$ & $(128 \mu \mathrm{g})$ & 0.06 \\
\hline $3 \cdot 20$ & 0.01 & Agroclavine & - & $(100 \mu \mathrm{g})$ & $0 \cdot 05$ \\
\hline $3 \cdot 36$ & $0 \cdot 1$ & Agroclavine & - & $(152 \mu \mathrm{g})$ & $0 \cdot 07$ \\
\hline 3.55 & $1 \cdot 0$ & Agroclavine & - & $(80 \mu \mathrm{g})$ & 0.04 \\
\hline
\end{tabular}

* Amounts added: $\mathrm{L}-\left[{ }^{14} \mathrm{C}\right]$ tryptophan, $4.5 \mu \mathrm{Ci}$ (sp. act. $54.68 \times 10^{3} \mu \mathrm{Ci} \mathrm{mmol}{ }^{-1}$ ); agroclavine, $2 \mathrm{mg}$. 
amounts of DMAT were detected. It was clear therefore that this strain of $C$. purpurea produces small amounts of DMAT during parasitic growth and its biosynthesis can be demonstrated by giving radiolabelled precursors (tryptophan and/or mevalonic acid). Further, this experiment demonstrated a biosynthetic block beyond DMAT. Since the next step involves $N$-methylation of DMAT by $S$-adenosyl methionine, the operation of this step was tested by incubating sclerotial tissue with $\left[\right.$ methyl $\left.{ }^{14} \mathrm{C}\right]$ methionine. Co-chromatography of tissue extract with authentic $N$-methyl DMAT showed no evidence of this intermediate in the tissue and no radioactivity in the corresponding region of the autoradiographed chromatogram. This indicates that the biosynthetic block was located at the DMAT $\rightarrow N$-methyl DMAT step.

The question therefore arose as to the extent to which subsequent steps in the ergoline biosynthetic pathway would function given appropriate substrates. Thus similar parasitic tissue was incubated with the clavine alkaloid intermediate agroclavine, prepared biosyntheticallyradiolabelled with ${ }^{14} \mathrm{C}$. This intermediate was taken up $(9 \cdot 1 \%)$ by the tissue from the incubation fluid (Table 1), and approximately half of this was detected in ergot alkaloid bases. $\left[{ }^{14} \mathrm{C}\right] \mathrm{Agroclavine}$ accounted for most of this alkaloid but a new blue fluorescent $(350 \mathrm{~nm})$ spot was evident at an $\boldsymbol{R}_{\boldsymbol{F}}$ value lower than that of all tripeptide ergot alkaloids. Cochromatography in three solvent systems with several fluorescent $(\Delta 9-10)$ ergot alkaloids, some having chromatographic mobility similar to the new alkaloid metabolite, indicated that it was LAA. Autoradiography of chromatograms showed that the LAA was radiolabelled and, from measurement of the radioactivity ( 2718 d.p.m., from half of the isolated LAA) and assuming its specific activity to be the same as the agroclavine from which it must quantitatively have been formed, a yield of $45 \mu \mathrm{g}$ was calculated. The electron impact mass spectrum showed an important ion $m / z 267\left(\mathrm{M}^{+}\right)$. Whereas all fluorescent $(\Delta 9-10)$ lysergic acid derivatives show the ion $m / z 267$ as a prominent fragment, the absence of any relevant ion of higher mass and the conformity of the mass spectrum with that of authentic LAA provide strong evidence for the identity of the promoted metabolite. From this and the chromatographic evidence it was concluded that LAA had been formed from agroclavine during incubation of the sclerotial tissue.

The role of lysergic acid as a precursor of the LAA end-product was confirmed (Table 1) without needing to use radiolabel.

Comparison of the effect of the concentration of phosphate in the incubation medium on the step tryptophan $\rightarrow$ DMAT and agroclavine $\rightarrow \rightarrow$ LAA showed (Table 2) that a high (1 M) concentration of phosphate inhibited DMAT synthesis but had no effect on the synthesis of LAA from agroclavine.

Since ergot sclerotia grow acropetally, the youngest tissue will be found at the point of attachment with the host (Shaw \& Mantle, 1980). Division of developing ergots of varying age

Table 3. Regional distribution of DMAT in C. purpurea sclerotia of different ages

\begin{tabular}{|c|c|c|c|c|}
\hline \multirow{3}{*}{$\begin{array}{l}\text { Time after } \\
\text { inoculation } \\
\text { (d) }\end{array}$} & \multicolumn{4}{|c|}{$\begin{array}{l}\text { Detection of DMAT } \\
\text { in region of sclerotial tissue indicated* }\end{array}$} \\
\hline & \multirow[b]{2}{*}{$\begin{array}{c}\text { Proximal } 3 \mathrm{~mm} \\
1981 / 2\end{array}$} & \multicolumn{2}{|c|}{$\underbrace{\text { Middle }}$} & \multirow[b]{2}{*}{$\begin{array}{c}\text { Distal } 3 \mathrm{~mm} \\
1981 / 2\end{array}$} \\
\hline & & 1981 & 1982 & \\
\hline 20 & - & - & NT & - \\
\hline 23 & - & + & NT & - \\
\hline 26 & - & + & NT & - \\
\hline 27 & - & NT & - & - \\
\hline 29 & - & NT & - & - \\
\hline 31 & - & NT & - & - \\
\hline 32 & - & + & NT & - \\
\hline 35 & - & ++ & ++ & - \\
\hline 40 & - & + & + & - \\
\hline
\end{tabular}

\footnotetext{
${ }^{*}$ NT, not tested; - , no DMAT detected $;+$, trace of DMAT evident $;++$, DMAT several-fold more abundant than +
} 


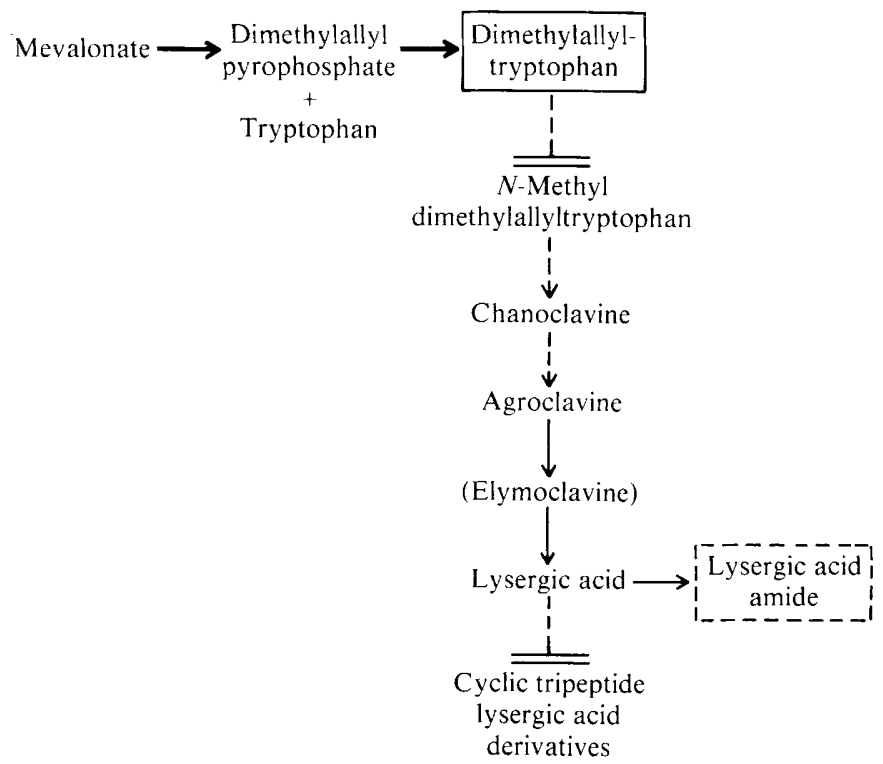

Fig. 1. Limitation of, and potential for, ergot alkaloid biosynthesis in a mutant strain of $C$. purpurea. Key $: \rightarrow$ steps operating normally; $--\rightarrow$, uncertain whether steps operate; $\|$, metabolic block; $\longrightarrow$, steps operating when appropriate substrates given; ( ), theoretical intermediate, though undetected. A solid line around a compound denotes a natural end-product; a dashed line around a compound denotes a promoted end-product.

into the youngest, older and oldest tissue (Table 3), in two consecutive years, was designed to seek the region and stage at which DMAT synthesis occurred in vivo. DMAT was never found in the youngest tissue (proximal $3 \mathrm{~mm}$ ). The central part of the sclerotia contained DMAT after 3 weeks' parasitic growth in 1981 and $4 \frac{1}{2}$ weeks in 1982 but, although quantitative determinations were not made, there were only at most trace amounts in relation to the usual yield of ergot alkaloids in $C$. purpurea $(0 \cdot 2-0 \cdot 4 \%)$. DMAT was not found in the distal part of sclerotia, which was composed largely of the shrivelled remains of the sphacelial fructification.

\section{DISCUSSION}

Since both the first step in ergot alkaloid biosynthesis and conversion of added intermediate alkaloids into a lysergic acid derivative were seen to operate in parasitic tissue of the mutant strain of $C$. purpurea, a biosynthetic scheme is proposed (Fig. 1), which indicates the step operating normally and those performed by the mutant fungus only when appropriate substrates were provided. Failure to biosynthesize the ergoline ring system appears to be the result of a metabolic block preventing $N$-methylation of DMAT by a methyl group donated from $S$ adenosyl methionine. This reaction, recently described as the second pathway-specific step in ergoline ring biosynthesis (Otsuka et al., 1979), may be catalysed by the $N$-methyl transferase recently detected in C. fusiformis (Otsuka et al., 1980). Isoprenylation of tryptophan to form DMAT, being the first pathway-specific step in ergot alkaloid biosynthesis, is therefore a potential target for conventional feedback control mechanisms. Consequently, this novel mutant strain of $C$. purpurea is a potential tool for studying control of DMAT synthesis in parasitic tissue.

Metabolism of the clavine alkaloid intermediate, agroclavine, and lysergic acid to the same end-product, LAA, is a novel biosynthesis of $C$. purpurea (Floss \& Anderson, 1980). It is possible that biosynthesis of cyclic tripeptide ergot alkaloids cannot operate in this fungus because of an additional mutation affecting the multi-enzyme complex responsible (Floss et al., 1974). At first sight this might imply that LAA is an intermediate in the biosynthesis of cyclic tripeptide ergot 
alkaloids. However, there is strong evidence from ${ }^{15} \mathrm{~N}$ studies with $C$. purpurea that the lysergamide nitrogen in the ergotoxine group of alkaloids is derived, not from [amide${ }^{15} \mathrm{~N}$ ]lysergic acid, but from the amino nitrogen of valine (Maier $e t$ al., 1971), or of alanine in the ergotamine group.

Concerning the derivation of the side chain of simpler lysergic acid derivatives, Castagnoli et al. (1970) showed that, although the ${ }^{15} \mathrm{~N}$ from $\mathrm{L}-\left[\mathrm{U}-{ }^{14} \mathrm{C},{ }^{15} \mathrm{~N}\right]$ alanine was incorporated into the amide nitrogen of lysergic acid $\alpha$-hydroxyethylamide by $C$. paspali, enhanced ${ }^{15} \mathrm{~N} /{ }^{14} \mathrm{C}$ ratio of the product implied that the incorporation was indirect. It was proposed that the side chain was derived from ammonia and pyruvate. The same organism incorporated lysergyl[2-14 $\mathrm{C}] \mathrm{alanine}$ into ergometrine. Thus, even for short-chain lysergic acid derivatives, LAA does not appear to be an intermediate. Even the occurrence of LAA as a natural product of $C$. paspali is regarded as a consequence of catabolism of lysergic acid $\alpha$-hydroxyethylamide (Kleinerova \& Kybal, 1973).

Therefore it is not clear whether, in the present studies, LAA was a direct amidation product of lysergic acid or resulted from degradation of a transient product of higher mass. In either case, the origin of the amide nitrogen is of interest and this organism could be used to explore this point.

Maier et al. (1980a) reported the axenic culture biosynthesis of cyclic tripeptide alkaloids by a C. purpurea mutant having only a metabolic block beyond chanoclavine-1-aldehyde (Maier et $a l ., 1980 b$ ). When fed with agroclavine or elymoclavine, the mutant produced the same alkaloids as the parent strain. Thus the uptake of exogenously-supplied alkaloid intermediates, and their access to the appropriate sub-cellular compartments of conventional alkaloid biosynthesis, does not appear to be a limiting factor.

Investigation into the control of alkaloid biosynthesis in axenic culture has shown that high concentrations of inorganic phosphate have an inhibitory effect, which can be partially overcome by addition of tryptophan or the tryptophan analogue thiotryptophan (Robbers et al., 1972; Krupinski et al., 1976). Whether inorganic phosphate can control the biosynthesis of tryptophan, lower endogenous inducer levels or directly inhibit or repress DMAT synthetase has been unclear. However, although in the present studies DMAT synthetase failed in a very high exogenous phosphate concentration, this must be regarded as non-physiological, implying that DMAT synthetase is not sensitive to phosphate under normal parasitic conditions. Further, the evidence of metabolism of agroclavine to LAA, even in $1 \mathrm{M}$-phosphate, indicates that phosphate control of alkaloid biosynthesis is also not mediated through the enzymes of this sequence of steps.

DMAT synthetase activity, though variable in amount, was restricted to sclerotial tissue which had largely ceased cell division. This conforms to the principle that fungal secondary metabolites are generally biosynthesized in an idiophase which is separated in time from the biomass-accumulating trophophase. However, the accumulation of DMAT only in trace amounts indicates that, in this mutant, DMAT synthetase, and/or its substrates, is under tight metabolic control by a mechanism which does not require ergoline end-product feedback regulation.

We thank Dr K. P. W. C. Perera for reference samples of DMAT and $N$-methyl DMAT prepared from $C$. fusiformis cultures. For J.W. and S.M.A. this research was in part fulfilment of the requirements for the Ph.D. degree of the University of London and was supported by Science and Engineering Research Council studentships.

\section{REFERENCES}

Arcamone, F., Chain, E. B., Ferretti, A., Minghetti, A., Pennela, P., Tonolo, A. \& Vero, L. (1961). Production of a new lysergic acid derivative in submerged culture by a strain of Claviceps paspali. Proceedings of the Royal Society B155, 26-54.

Banks, G. T., Mantle, P. G. \& Szczyrbak, C. A. (1974). Large-scale production of clavine alkaloids by Claviceps fusiformis. Journal of General Microbiology 82, 345-361.
Castagnoli, N., Corbett, K., Chain, E. B. \& THomas, R. (1970). Biosynthesis of $N$ - $(\alpha$-hydroxyethyl)lysergamide, a metabolite of Claviceps paspali. Biochemical Journal 117, 451-455.

Corbett, K., Dickerson, A. G. \& Mantle, P. G. (1974). Metabolic studies on Claviceps purpurea during parasitic development on rye. Journal of General Microbiology 84, 39-58.

Dickerson, A. G., Mantle, P. G. \& Szczyrbak, 
C. A. (1970). Autolysis of extracellular glucans produced in vitro by a strain of Claviceps fusiformis. Journal of General Microbiology 60, 403-415.

Floss, H. G. \& ANDERSON, J. A. (1980). Biosynthesis of ergot toxins. In The Biosynthesis of Mycotoxins, pp. 17-67. Edited by P. S. Steyn. New York: Academic Press.

Floss, H. G., Tcheng-Lin, M., Kobel, H. \& STADleR, P. (1974). On the biosynthesis of peptide ergot alkaloids. Experientia 30, 1369-1370.

HofmanN, A. \& TSCherTER, H. (1960). Isolierung von Lysergsäure-Alkaloiden aus der mexikanischen Zauberdroge Ololiuqui (Rivea corymbosa). Experientia 16, 206-207.

Kleinerova, E. \& Kybal, J. (1973). Ergot alkaloids IV. Contribution to the biosynthesis of lysergic acid amides. Folia microbiologica 18, 390-392.

Krupinski, V. M., Robbers, J. E. \& Floss, H. G. (1976). Physiological study of ergot: induction of alkaloid synthesis by tryptophan at the enzymic level. Journal of Bacteriology 125, 158-165.

MaIer, W., ERGe, D. \& Groger, D. (1971). Zur Biosynthese von Ergotoxinalkaloiden in Claviceps purpurea. Biochemie und Physiologie der Pflanzen 162, 559-569.

Maier, W., Erge, D. \& Groger, D. (1980a). Mutational biosynthesis in a strain of Claviceps purpurea. Planta medica 40, 104-108.
Maier, W., Erge, D., Schmidt, J. \& Groger, D. $(1980 \mathrm{~b})$. A blocked mutant of Claviceps purpurea accumulating chanoclavine-1-aldehyde. Experientia 36, 1353-1354.

Mclaughlin, J. C., Goyan, J. E. \& Paul, A. G. (1964). Thin-layer chromatography of ergot alkaloids. Journal of the American Pharmaceutical Association 53, 306-310.

Otsuka, H., Anderson, J. A. \& Floss, H. G. (1979). The stage of $N$-methylation in ergot alkaloid biosynthesis. Journal of the Chemical Society. Chemical Communications, 660-662.

Otsuka, H., Quigley, F. R., Groger, D., Anderson, J. A. \& Floss, H. G. (1980). In vivo and in vitro evidence for $N$-methylation as the second pathwayspecific step in ergoline biosynthesis. Planta medica 40, 109-119.

Robbers, J. E. L., Robertson, L. W., HornemanN, K. M., Jindra, A. \& Floss, H. G. (1972). Physiological studies on ergot: further studies on the induction of alkaloid synthesis by tryptophan and its inhibition by phosphate. Journal of Bacteriology 112, 791796.

Shaw, B. I. \& Mantle, P. G. (1980). Parasitic differentiation of Claviceps purpurea. Transactions of the British Mycological Society 75, 117-121. 